\title{
Synonymy Relationships between the Subjunctive and the New Infinitive in the Syntactic
} Aspect

\author{
PhD. Mimoza Zekaj \\ Department of Albanian language, \\ University of Gjirokastra, Albania,
}

\begin{abstract}
The object of this study is the relationship between the subjunctive mood and infinitive in the Albanian language. Subjunctive is one of the inherited moods in Albanian. Apart from the indicative, subjunctive is also widely used, because it expresses a variety of modal meanings. The frequency of subjunctive mood usage, mainly in the south dialect, is related to its use as a synonym to the infinitive. The subjunctive mood coincides with the non-finite forms, especially the infinitive. This coincidence is evident on the syntactic aspect and its functional point of view, as well. The synonymy of infinitive to the subjunctive is observed in the present standard Albanian language. In most of the infinitive uses, we can easily replace them with the subjunctive, without causing any changes in the modality or relationship with other syntactic units. This substitution is not always possible. This occurs in the category of subordinate or main clauses and simple sentences in the function of the simple predicate. Nevertheless, nowadays, we notice synonymy relationships between the subjunctive and infinitive, especially with the grammatical constructions that denote meanings of purpose. In the relative clauses, this synonymy is much more limited. Substitution of the infinitive with the subjunctive in such constructions can bring slight changes of meaning. Anyway, we should emphasize that despite the value of the infinitive, the subjunctive mood is widely used in the national literary language.
\end{abstract}

Keywords: synonymy relationship, subjunctive, infinitive,syntactic aspect, albanian language

\section{Introduction}

Subjunctive is one of the inherited moods in Albanian language. Apart from the indicative, subjunctive is widely used, because it expresses a variety of modal meanings. This grammatical mood is contrasted with other moods in the aspect of construction (with the use of the preceding particle të), (Sh., Demiraj, 1977:103), as well as its special modal meaning (its core meaning is that of possibility). The frequency of this mood (particularly in the south dialect), is connected with its use as a synonym of the infinitive.

Centuries before the publication of the first Albanian book, known today, the Gheg dialect (northern dialect) has created a nonfinite form of the type me ba (to do) (Sh., Demiraj, 1973:422), which has the value of the infinitive. During a later period, in all Albanian dialects, there is distinguished a nonfinite form of the type për të bërë / për të ba (to do) with the value of infinitive (paskajore) and limited syntactic functions.

In order to present the relationship between these categories, thus subjunctive mood and infinitive, in some synonymy constructions, as well as the tendencies of language development, we are going to confine our attention to the approaches various linguists have provided at different periods.

In the grammars of Albanian language before 50-ies, these relationships have been regarded as a very close synonymy. According to Cipo (K.,Cipo, 1949:115): "Coniunctivi is sometimes characterized by other functions that allow its independent use. These functions include: a. To replace the infinitive that the Tosk dialect lacks. E.g. Po shkoj të marr ushqimin =me marrë ushqimin (l'going to take the food $=$ to take the food). $\underline{b}$. Fill in the category of person the imperative lacks..." Sheperi (I.,D.,Sheperi, 2001:90), has thoroughly treated the syntactic problems of this period. He states: "Instead of the infinitive Tosk dialect uses: a. subjunctive mood e.g. me shkrue = të shkruaj, të shkruash (to write) etc. b. neutral type of participle adjective with the preposition pwr, e.g., "me shkrue = për të shkruar" (to write).

In later years, Demiraj (Sh., Demiraj, 1973: 425) writes: "In Greek and Bulgarian language, the substitution of the infinitive by subjunctive remains a general linguistic fact, whereas in Albanian language during the latest centuries, it is observed an 
opposite tendency. This is related to the tendency to create non-finite forms that appear as synonyms for the subjunctive and have been much more used compared to subjunctive".

For the linguist J. Mita (J., Mita, 2006:172), "Subjunctive does not have a time reference, but it is much more similar with the infinitive". Çeliku, (M. Çeliku, 2000: 55) has an important contribution to non-finite forms, especially for the relationships of infinitive with subjunctive. He emphasizes that some uses of infinitive of the type për të bërë (to do) under the circumstances of literary Albanian language existence are controversial from the normative aspect. Statistics show that, in the standard Albanian language, the subjunctive is used in most cases in the function of the subject.

The subjunctive in such cases is much more used compared to the infinitive, but it can hardly be regarded as a normative construction and able to compete with the subjunctive. Also, in the journalistic genre, where cases of the infinitive functioning as subject are present, the subjunctive predominates after constructions as jam + emër (to be + noun), jam + mbiemër (to be + adjective), after verbs dua (want), dëshiroj (desire), mendoj (think), them (say) etc.

The coincidence of the subjunctive mood with the non-finite forms, especially with the infinitive and the type me ba (to do) and për të bërë (to do), is proved in the syntactic aspect from the functional point of view.

The synonymy of the subjunctive with the infinitive should be taken into consideration only within the Albanian language system, but not on the comparative aspect. We highlight this idea, because in those subordinate clauses in which the subjunctive functions as the infinitive of the northern dialect or as an infinitive of literary language, it will not be possible to distinguish the main modality of this mood. In such uses, it would not be possible to contrast this finite form with the indicative form based on the modality truthfulness - falsehood. E.g. Po shkoj në biblotekë (që) të lexoj (l'm going to the library to read.); and Tjetër herë s'dua të bisedoj (Next time I don't want to talk.). This synonymy is impossible in those languages where the infinitive is not used independently.

It is known that the substitution of the subjunctive is a Balkan phenomenon. As far as this phenomenon is concerned, linguists have had different approaches that are not the object of this study.

In the Albanian standard language the synonymy of infinitive with the subjunctive can clearly be distinguished in both the old form of me and the new form of the infinitive për të. In this study we will give special attention to the relationship of the subjunctive and the new type of infinitive për të bërë (to do). Sh. Demiraj, highlights: "At later periods in all dialects of Albanian language, a new non-finite form of the type për të bërë (to do) has been created, similar to an infinitive with limited syntactic functions. The non-finite form of the type me ba (to do) is synonymous with the subjunctive mood either followed or not with subordinate conjunctions in most of its functions. Also, the non-finite form of the type për të bërë (to do) is synonymous with the subjunctive mood is some of its uses", (Sh., Demiraj, 1973: 423).

This substitution is a complete one. We can speak in terms of an absolute synonymy in the use of both forms interchangeably. In most uses, the infinitive can be substituted with the subjunctive without any change in its modality and connection with other syntactic units. These substitutions can be made also in subordinate clauses. The subjunctive mood and infinitive can be mainly used in some sentence constructions that modify or explain the main clause as well as in other constructions with adverbial nuances.

Even in these types of sentences, where the nuances of coincidences are evident, there are cases of incongruity, due to the fact that the infinitive is an abstract verb form (S. Mansaku, 1982: 140). This assigns a general action without grammatical elements (that indicate the grammatical categories) and it expresses its grammatical meanings through the context where the infinitive is placed. E.g.: Të ardhurit e vendosur në prona të tjetërkujt, do të dilnin të protestonin kundër një vendimi të qeverisë për t'i shkulur prej andej, qoftë edhe duke u shembur shtëpitë, po të mosbindeshin me të mire...Prandaj tani më vjen për të qarë (F. Kongoli, 2005: 118). (The ones settled in other people's land, would go out to protest against the decision of the government to send them away, even to pull down the houses, in cases of disobedience).

The subjunctive mood cannot always be replaced by the infinitive as well as the infinitive cannot always be used instead of the subjunctive. The subjunctive displays a wide and irreplaceable usage is some categories of subordinate clauses, in main clauses or in independent sentences functioning as a simple predicate. We think that this comes as a result of a totality of grammatical, semantic and structural features as well as the modality of this mood. E.g.: Ikë e bjerë, atë të bëç që të viç në vehte dhe mos rri akoma në këmbë, pa punët $i$ bëj unë. Ta k’anda në shtëpi, të ka duk dhe puna, ke kohë të uleç në shesh, të hedhësh nja di gjëlpëra si ka dhënë zoti. (M., Kokalari, 1939: 35). (Go and have a sleep, this should you 
do to pull yourself together, don't stand here, I will do the house works. It is pleasing to be home, you work considerably, have time to relax, to mend clothes as you are blessed to this).

1. The subjunctive mood is a conjugated verb form (Akademia e Shkencave, 2002: 293), which has formal means in order to express this grammatical category. E.g.:. Ç'prisnit të dëgjonit nga shpirtrat. (What did you expect to hear from the souls); Kam nevojë të shkoj në... (I need to go to ...); Të ngriheshin e të ikinin. (To get up and go).

2. The subjunctive mood expresses also the modality of falsity (F., Agalliu, 1988: 18), thus the attitude of the speaker towards an action existing in his mind, but obviously appears not to be performed, have been performed or to be performed in reality. The infinitive marks an action, but not tending to react about the truth of its realization. It simply denotes the action. E.g.: Ndofta kanë ardhur të qahen (Perhaps they have come to complain); Ishte më i përshatshëm për të të gëricur, ashtu siç qe më i përshtatshëm për të dhënë krenarinë e saj si vajzë udhëheqësi. (I., Kadare, 2003). (She was the right person to annoy, as well as the best to share her pride as the daughter of a leader).

3. The subjunctive mood has the category of tense. It is a mood that has the present, past, present perfect and past perfect tense.

4. The subjunctive mood has the category of person and number. It has three persons and two numbers. The infinitive, not only in Albanian language, but almost in all languages that have this form, is characterized as impersonal verb form (S. Mansaku, 1982: 149).

5. The subjunctive has the grammatical category of diathesis. Verb forms of the passive conjugation of this mood are constructed by some linguistic means. This grammatical category is characteristic even for the infinitive, which is built by the particle $u$ or through the use of the auxiliary verb jam. Diathesis is the single grammatical category of the infinitive easily distinguishable, which is expressed formally the same as other person verb forms. Not only in Albanian language, but the most part of languages that have the infinitive, distinguish an active and a passive infinitive (S. Mansaku, 1982: 144).

E.g. ...Se ishte vonë dhe ishte e pamundur për t'u kthyer, për të mos na gëlltitur terri, secili kishte filluar të jepte copa të vetvetes. Kjo s'është për t'u gëzuar, por për të vënë kujën. (I., Kadare, 2003: 51, 54). (Because it was too late to return, not be swallowed up by the dusk, everybody had begun to give from themselves. This is not to be delighted, but to weep).

6 . The subjunctive mood can be used even in one-member sentences with undefined or generalized person, giving imaginative states or actions (Akademia e Shkencave, 2002: 382-383). E.g: Si mund ta kuptoje se ç'donte të thoshte? Më mirë të dish se sa të kesh. (How could you understand what she wanted to say? Better known than have it).

7. During the historical evolution the subjunctive mood has received additional meanings despite its fundamental modal one. This is noticed in the present tense of the subjunctive, a tense which can also express the modality of desirability in the form of a wish or curse, in the form of an order or request (Sh., Demiraj, 1977: 105). E.g.: Të marrtë zoti mendtë! Më ke ngrënë jetën, të hëngërt mortja!

Due to this status of the subjunctive mood, even in some subordinate clauses can be used the subjunctive and not the infinitive. Most of the subordinate clauses where the subjunctive is used are: some time clauses expressing simultaneous activities or after time activities, some conditional clauses, clauses of result, manner, and concession or in object clauses type. Indefinite pronouns, different adverbs of indefinite meaning, conjunction phrases relative pronoun që (that) (T., Kelmendi, 2006: 13), etc., serve as linking means for the expression for the abovementioned syntactic relationships. E.g.: Kur të takohemi do të flasim përsëri. (When we meet, we'll talk again). Sapo çupa u mundua të ikte, beu e arriti. (As soon as the girl attemped to leave, the pardon reached her). Sado guxim të kini, nuk e vërtetoni dot atë që thashë unë. (Despite the bravery you have, you cannot provide proof for what I said). Nuk do t'i ndodhte ndoshta kjo, sikur ajo të mos ishte aktore, dhe jo vetëm kaq, por aktorja që lozte "pulëbardhën". (This perhaps would not have happened to her, if she had not been an actress, and what's more, the actress who played the innocent part).

This attitude is fully reinforced in the book Dialektologjia e gjuhës shqipe (1974: 393). In the dialect of Hot and other northern dialects, it can be noticed the frequent use of the infinitive of the type me punue, used to express those relationships denoted by the subjunctive mood in the literary language. Anyhow, there are some conjunctions, conjunction phrases or verb forms which appear as set elements, originate from subjunctive forms. Such forms include: kur (when), pasi (after), deri ç' (till), n'dasht (if it wishes), kur t'vish (when you come), kur t'niset (when it goes), pasi t'marrsh (after you take), pasi t'hash ata merr tjetrën (after you eat that take the other), deri çi t'des s'e harroj at gas (till I'm dead I want forget that 
amusement), n'dashtmo:n'dasht t'shkoj elle aj me ta"(if he wishes, let him go with them). Different linguists have noticed that the subjunctive mood has a higher frequency in the southern dialect than in the northern one. This can be explained by the lack of infinitive in the Tosk dialect.

In all the cases where the subjunctive is used instead of the true infinitive, the modality of this mood equals zero. This phenomenon is clear in the use of the subjunctive following the semi-auxiliary verbs mund (can) and duhet (have to) or verbs and syntagm that state the will of the speaker. Some examples of the verbs are: dua (want), uroj (wish), lejoj (allow), preferoj (prefer), ndaloj (prevent), kundërshtoj (contradict), dyshoj (doubt), pres (expect), dëshiroj (desire), porosit (order) etc.

Even nowadays in many constructions there are distinguished synonymy relationships between the subjunctive and the infinitive form për të (to) + participle. Both forms are widely used in cases of purpose constructions. Eg.: Pas rënies së trishtë, Qerosi bëri çmos për të gjetur udhën (që të gjente udhën) dhe mënyrat që të ngjitej (për t'u ngjitur) prapë në botën e sipërme. Doja të jepja përshtypjen, se lëvizja për të gjetur (të gjeja) një vend të përshtatshëm për të qëndruar (të qëndroja), ashtu siç bënin të porsambërriturit. (After the gloomy fall, the baldheaded tried hard to find the way (to find the way) and means to climb to the upper world again. I wanted to give the impression that I moved to find (to find) an appropriate place to stay (to stay), as the ones who had just arrived did).

In the relative constructions the synonymy relationships are rather limited and their substitution can bring changes of meaning. In our opinion this comes from the origin of the formants me and për of the infinitive. These formants have once been prepositions (S., Mansaku, 1982:139) and have played certain syntactic functions. Today, they have lost every marker as a preposition and have been transformed in infinitive indicators, the same as has occurred with other formants of Albanian language. In these cases of use, the infinitive appears as defining the noun. Generally, the noun that is qualified by the infinitive is a noun with the meaning of desire, possibility, impossibility, will etc.: Përpjekja për të futur kompjuterin (të fuste kompjuterin) mund të quhej e dështuar. (The attempt to make use of the computer could be called a failure). Mua më mungonte vullneti për të vepruar (të veproja), por jo dëshira. (I missed the will to act, but not the desire.) Do të thoshje se, po t'i jepej mundësia për të bërë sqarimin (të bënte sqarimin), ishte gati të merrte në telefon instancat përkatëse. (You wanted to say that once he had the possibility to give the explanation, he was ready to call the relevant institutions). We think that in these cases the use of infinitive is very common.

The infinitive is widely used even in sentences where the agent is not expressed. The verb form in these sentences has clearly defining functions of the noun and it reinforces the action. In these cases the substitution with the subjunctive is possible and can generate any change of meaning. Eg.: Duhej të ishe aty, mu në sytë e të gjithëve, që të zgjoheshe një grimë nga dremitja për ta dalluar (që ta dalloje). (You should have been there, to wake up and recognize). (I.,Kadare, 2003: 76), ...Pra, spektakël klasik për t'i hedhur (që t'i hidhte) hi syve të turmës. (Hence, a classic spectacle to deceive the crowd). (I., Kadare, 2003: 82). The use of the infinitive instead of the subjunctive in subordinate predicate clause after the verbs mbetem (remain) and lë (let) has a high frequency and is of a special significance. E.g.: Në një farë kohe më qe dukur se ajo kishte mbetur , për të buçitur prapë më fort (I., Kadare, 2003) (For a while it appeared as if she had remained to scream louder). Ai e kishte lënë të lirë për të gjetur rrugën e daljes (I.,Kadare, 1996). (He had set her free to find the exit). In the literary works the subjunctive is mostly preferred by the authors.

For centuries, the Albanian language has created the non-finite form of the type për të bërë, which has gradually come into use in some typical functions of the infinitive. Since the pre-literary period, the Albanian language has always developed the type me të ardhur, një të ardhur, that belong to a relatively later period. They are also synonymous with the subjunctive preceded by any subordinate conjunctions in some of their uses (Sh., Demiraj, 1973: 425). It is observed that phrases such as me + të ardhur and një + të ardhur are built by means of neutral verbal nouns, which like the respective verbs denote physical or psychic- physiological actions. Each one is used to express a fast action immediately followed an action presented by the verb of the head clause.

Also, these phrases of verbal value appear with a higher frequency in the southern dialect and narrative style.

U nis pa lindur dielli - (para se të lindte dielli) etj. (He left before the sun rose), (before the sunrise) etc.

Me të nisur, ose një të nisur - (porsa të nisesh), (as soon as she left) 
Finally, we have to once more emphasize the fact that nowadays, the subjunctive mood is much more used in the standard language, in spite of the value of the infinitive and some constructions with the non-finite forms. It can be seen in all its syntactic functions, thanks to the linguistic characteristics of this mood.

\section{References}

[1] Dialektologjia shqiptare II. (1974), Tiranë,.

[2] Gramatika e gjuhës shqipe I. (2002), Tiranë.

[3] Gramatika e gjuhës shqipe II. (2002), Tiranë,.

[4] F.,Agalliu, ( 1978). Çështje të morfologjisë së gjuhës së sotme shqipe, Tiranë,

[5] F.,Agalliu (1983). Vëzhgime mbi formën gramatikore pa + pjesore, në "SF", 3,.

[6] K., Cipo (1949). Gramatika shqipe, Tiranë,.

[7] M., Çeliku,(2000). Format e pashtjelluara të foljes në gjuhën e sotme shqipe, Tiranë.

[8] Sh., Demiraj, (1973). Studime rreth historisë së gjuhës shqipe, Tiranë.

[9] Sh., Demiraj, (1976). Morfologjia historike e gjuhës shqipe II, Tiranë.

[10] Sh.,Demiraj, (1962). Forma gramatikore perifrastike për + emër foljor i gjinisë asnjanëse në trajtë të pashquar, në Konferencën e Parë të Studimeve Albanologjike, Tiranë.

[11] Th., Dhima, (2005). Gjuha shqipe sintaksa, Tiranë.

[12] T., Kelmendi, (2006). Kështjellat e sintaksës, Prishtinë.

[13] E., Likaj, (1978). Mbi format analitike në gjuhën shqipe, në "SF", 3.

[14] S., Mansaku, (1982). Paskajorja e shqipes dhe kategoritë gramatikore të saj, në "SF", 1.

[15] J.,Mita, ( 2005). Hyrje në sintaksën gjenerative, Prishtinë.

\section{Corpus - literary works}

[1] I., Kadare, (1996). Spiritus, Tiranë.

[2] I., Kadare, (2003). Vajza e Agamemnonit, Tiranë.

[3] M., Kokalari, (1939). Siç më thotë nënua plakë, Tiranë.

[4] F., Kongoli, (2005). Te porta e Shën Pjetrit, Tiranë.

[5] M., Kuteli, Vepra të zgjedhura. 